\title{
EKSTRAK AIR TANAMAN SELEDRI (APIUM GRAVEOLENS) TERHADAP PENINGKATAN VOLUME URIN TIKUS PUTIH
}

\author{
Adita Silvia Fitriana \\ Program Studi Farmasi S1, Stikes Harapan Bangsa Purwokerto \\ aditasilvia@gmail.com
}

\begin{abstract}
ABSTRAK
Pengolahan seledri sebagai diuretik dilakukan oleh masyarakat dengan berbagai cara. Sejauh ini, proses persiapan ekstrak seledri yang paling efektif belum diketahui. Penelitian ini bertujuan untuk menguji efek diuretik dari berbagai persiapan ekstrak seledri. Penelitian ini dilakukan menggunakan ekstrak air seledri yang dibuat sesuai dengan kebiasaan masyarakat, menggunakan aquades sebagai kontrol negatif dan HCT sebagai kontrol positif. Uji efektivitas ekstrak air seledri sebagai diuretik dilakukan pada tikus putih jantan dengan mengukur volume urin setiap jam selama enam jam. Hasil penelitian menunjukkan bahwa volume urin terbesar diperoleh dari ekstrak seledri mendidih.
\end{abstract}

Kata kunci: seledri, diuretik, tikus

\begin{abstract}
Processing of celery as diuretic is done by society in various ways. So far, the most effective preparation process of celery extract has not been known. This research aims to examine the diuretic effect of various celery extract preparation. This research was conducted using celery water extract which is made in accordance with the people's habit, using aquades as a negative control and HCT as a positive control. The effectiveness test of celery water extract as diuretic was done on white male rat by measuring the urine volume every hour for six hours. The results showed that the largest urine volume is obtained from the boiling celery extract.
\end{abstract}

Keywords: celery, diuretic, rat 


\section{PENDAHULUAN}

Indonesia merupakan negara yang kaya akan sumber bahan obat alam. Salah satu tanaman yang dapat dimanfaatkan sebagai obat adalah seledri (Apium graviolens L.). Seledri merupakan tanaman dari suku Umbelliferae yang sering digunakan sebagai bahan makanan. Beberapa khasiat seledri antara lain dapat digunakan untuk menurunkan tekanan darah, diuretik (Kemenkes RI, 2011), antiimflamantory (Powanda dan Rainsford, 2011), antioksidan (Momin dan Nair, 2002), antijamur dan antikanker (Fazal dan Singla, 2012).

Tanaman seledri mengandung beberapa zat kimia yang bermanfaat bagi tubuh seperti, apigenin, manitol, apiin, fitosterol, kalium, magnesium, besi, vitamin A, K, dan C. Senyawa manitol dan apiin merupakan senyawa yang berkhasiat sebagai diuretik (Saputra dan Fitria, 2016). Apiin adalah senyawa golongan flavonoid yang terdapat pada seluruh bagian tanaman seledri. Apiin bersifat polar sehingga larut dalam pelarut-pelarut polar seperti metanol, etanol, dan air (Kusnadi, 2017)

Beberapa penelitian mengenai aktivitas diuresis tanaman seledri telah dilakukan, seperti penelitian yang dilakukan oleh Evanti (2012) dan
Susilawati, dkk. (2003) menunjukan bahwa ekstrak alkoholl tanaman seledri dapat memberikan efek diuresis pada tikus putih. Selain itu, infusa daun seledri dengan konsentrasi $10 \%$ juga terbukti dapat memberikan efek diuresis pada tikus putih jantan (Setiyawan, 2005).

Pemanfaatan tanaman seledri sebagai obat dilakukan masyarakat dengan berbagai cara, ada yang menumbuk seledri sampai halus kemudian ditambahkan air dan diperas kemudian direbus sampai mendidih, merebus langsung tanaman seledri dengan beberapa gelas air hingga mendidih atau hingga mencapai volume tertentu, atau dengan cara diolah menjadi juice. Berdasarkan studi literatur yang telah dilakukan, belum ada informasi mengenai cara pengolahan ekstrak tanaman seledri yang paling efektif sebagai diuresis. Oleh karena itu, hasil penelitian ini diharapkan dapat memberikan informasi mengenai cara penyiapan ekstrak air tanaman seledri yang dapat memberikan efek diuresis paling besar.

\section{METODE PENELITIAN}

\section{Alat-alat Penelitian}

Alat-alat yang digunakan pada penelitian ini adalah timbangan, kandang metabolik, sonde, hot plate, alat-alat gelas 
(Pyrex) dan alat-alat standar laboratorium lainnya.

\section{Bahan-bahan Penelitian}

Bahan-bahan yang digunakan pada penelitian ini adalah tanaman seledri (Apium graveolens L.), tikus putih jantan, akuades, dan hidroklorotiazid (HCT).

\section{Prosedur Penelitian}

\section{Penyiapan Sampel}

Sampel ekstrak air tanaman seledri dibuat dengan cara yang berbeda-beda:

a. Sebanyak $100 \mathrm{~g}$ tanaman seledri yang telah dicuci bersih ditambah $500 \mathrm{~mL}$ akuades kemudian dididihkan (Sampel A)

b. Sebanyak $100 \mathrm{~g}$ tanaman seledri yang telah dicuci bersih dibuat juice dengan $500 \mathrm{~mL}$ akuades dan disaring (Sampel B)

c. Sebanyak $100 \mathrm{~g}$ tanaman seledri yang telah dicuci bersih ditumbuk kemudian ditambahkan $500 \mathrm{~mL}$ akuades dan disaring (Sampel C)

Penggunaan pelarut air bertujuan untuk menyesuaikan dengan penggunaan di masyarakat selain itu pelarut air merupakan pelarut yang murah dan paling mudah didapatkan serta paling aman bagi tubuh.

\section{Pengujian Efek Diuresis pada Hewan} Coba
Hewan uji yang digunakan adalah tikus putih jantan dengan berat 100-200 gram, berumur 2-3 bulan dan belum pernah digunakan untuk penelitian. Sebanyak 15 ekor tikus dibagi ke dalam 5 kelompok perlakuan yaitu kelompok kontrol positif yang diberi HCT, kelompok kontrol negatif yang diberi akuades, dan tiga kelompok uji yang diberi ekstrak air tanaman seledri dengan cara penyiapan ekstrak yang berbeda-beda yaitu dididihkan, dibuat juice, dan ditumbuk.

Hewan uji diadaptasikan terlebih dahulu selama 7 hari di dalam kandang metabolit dengan diberi makan dan minum secara ad libitum dan terkontrol. Sebelum dilakukan pengujian, hewan uji dipuasakan minimal selama 18 jam dengan hanya diberi minum untuk mengurangi pengaruh makanan terhadap absorpsi sampel.

Pemberian sampel dilakukan secara oral dengan dosis yang sama $(1,26 \mathrm{~g} / \mathrm{kg}$ BB) berdasarkan berat badan tikus. Setelah diberi perlakuan, hewan uji dimasukkan ke dalam kandang metabolik untuk mempermudah proses penampungan dan pengukuran urin. Pengukuran volume urin dilakukan pada jam ke-1, 2, 3, 4, 5, dan 6 . Selama perlakuan hewan uji tidak diberi makan. 


\section{Analisis Data}

Data volume urin yang diperoleh dianalisis dengan analisis varian satu arah (One Way ANOVA) menggunakan program SPSS (Statistical Programs for Social Scientific) versi 20 dan dilanjutkan dengan uji LSD (Least Significant Difference).

\section{HASIL DAN PEMBAHASAN}

Penelitian ini merupakan penelitian eksperimental yang bertujuan untuk mengetahui efek diuresis ekstrak air tanaman seledri dengan cara penyiapan sampel yang berbeda-beda. Data rata-rata volume urin tiap waktu pengamatan ditampilkan pada Tabel 1.

Tabel 1. Data rata-rata volume urin tiap waktu pengamatan

\begin{tabular}{|c|c|c|c|c|c|c|}
\hline \multirow{2}{*}{$\begin{array}{c}\text { Kelompok } \\
\text { Perlakuan }\end{array}$} & \multicolumn{6}{|c|}{ Volume Urin Tiap Jam (mL) } \\
\cline { 2 - 7 } & $\mathbf{1}$ & $\mathbf{2}$ & $\mathbf{3}$ & $\mathbf{4}$ & $\mathbf{5}$ & $\mathbf{6}$ \\
\hline $\mathrm{A}$ & 0.24 & 0.22 & 0.19 & 0.20 & 0.25 & 0.16 \\
\hline $\mathrm{B}$ & 0.21 & 0.11 & 0.14 & 0.17 & 0.10 & 0.08 \\
\hline $\mathrm{C}$ & 0.26 & 0.08 & 0.17 & 0.09 & 0.17 & 0.26 \\
\hline $\mathrm{K}(+)$ & 0.15 & 0.25 & 0.44 & 0.25 & 0.33 & 0.25 \\
\hline $\mathrm{K}(-)$ & 0.08 & 0.11 & 0.10 & 0.04 & 0.06 & 0.07 \\
\hline
\end{tabular}

Gambar 1 menampilkan kenaikan volume urin kumulatif selama waktu pengamatan. Kelompok perlakuan kontrol negatif menghasilkan volume urin kumulatif paling sedikit, yaitu $0,45 \mathrm{~mL}$ sedangkan kelompok kontrol positif menghasilkan urin paling banyak sebesar
1,67 mL. Hal ini disebabkan oleh tidak adanya zat aktif yang dapat meningkatkan volume urin pada kontrol negatif, dalam hal ini adalah akuades (Zainudin, dkk., 2015).

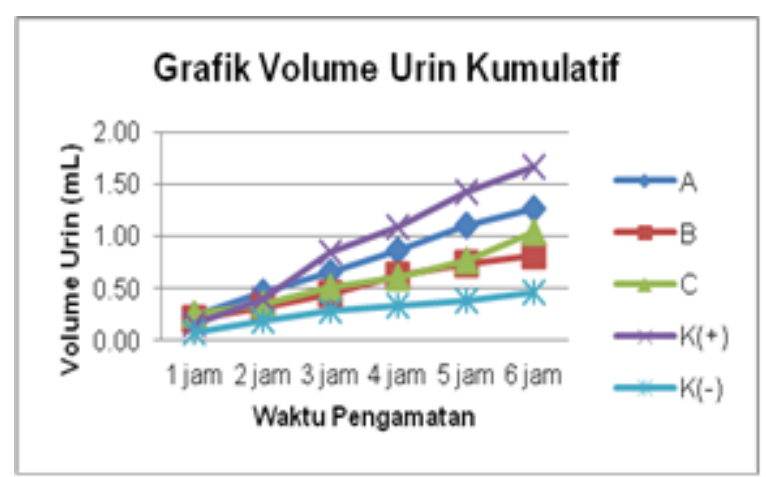

Gambar 1. Grafik Volume Urin Kumulatif

Pemberian ekstrak air tanaman seledri secara umum dapat meningkatkan volume urin tikus putih walaupun volume urin yang dihasilkan masih lebih rendah dari kontrol positif. Gambar 1 menunjukkan bahwa tikus yang diberi sampel A memproduksi urin lebih banyak dibandingkan dengan tikus yang diberi sampel B dan C. Hal ini menunjukkan bahwa perubahan suhu melalui perebusan mempengaruhi kandungan senyawa aktif yang terdapat dalam ekstrak seledri (Farhana, dkk., 2015). Dengan bertambahnya suhu, kelarutan zat aktif yang diekstrak semakin besar (Yuliantari, dkk., 2017).

Untuk menganalisis ada tidaknya perbedaan nyata terhadap masing-masing 
kelompok perlakuan, dilakukan uji ANOVA. Hasil Uji ANOVA menunjukkan bahwa ada perbedaan yang signifikan dari lima kelompok perlakuan, dengan nilai signifikansi sebesar $p=0,000(p<0,05)$.

Tabel 2. Hasil uji ANOVA

ANOVA

Volume Urin

\begin{tabular}{|l|r|r|r|r|r|}
\hline & $\begin{array}{c}\text { Sum } \\
\text { of } \\
\text { Square } \\
\text { s }\end{array}$ & df & \multicolumn{1}{|c|}{$\begin{array}{c}\text { Mean } \\
\text { Square }\end{array}$} & F & Sig. \\
\hline $\begin{array}{l}\text { Between } \\
\text { Groups } \\
\text { Within } \\
\text { Groups } \\
\text { Total }\end{array}$ & .141 & 4 & .035 & 9.080 & .000 \\
\hline
\end{tabular}

Hasil uji LSD menunjukkan bahwa pemberian HCT (kontrol positif) tidak berbeda nyata dengan pemberian sampel A, dengan nilai signifikansi $\mathrm{p}=0,073(\mathrm{p}>$ 0,05) dan menunjukkan perbedaan yang nyata terhadap sampel B dan C. Hal ini menunjukkan bahwa cara penyiapan ekstrak air tanaman seledri dengan cara didihkan menghasilkan lebih banyak senyawa yang berperan sebagai diuretik dibandingkan dengan cara penyiapan ekstrak dengan dibuat juice atau ditumbuk.

\section{KESIMPULAN}

Berdasarkan penelitian yang telah dilakukan dapat disimpulkan bahwa ekstrak air tanaman seledri memiliki efek diuretik terhadap tikus putih. Efek diuretik paling besar diperoleh dari ekstrak yang disiapkan dengan cara perebusan hingga mendidih.

\section{DAFTAR RUJUKAN}

Evanti, A.M., 2012, 'Efek Diuresis Ekstrak Seledri (Apium graviolens L.) pada Tikus Putih Jantan (Rattus norvegicus)'. Skripsi. Fakultas Kedokteran Universitas Sebelas Maret, Surakarta.

Farhana, H., Maulana, I.T., \& Kodir, R.A., 2015, 'Perbandingan Pengaruh Suhu dan Waktu Perebusan terhadap Kandungan Brazilin pada Kayu Secang (Caesalpinia sappan Linn.)', Prosiding Penelitian SPeSIA Unisba. 18-20 Agustus 2015, Bandung, Indonesia, pp. 19-25.

Fazal, S.S., \& Singla, R, 2012, 'Review on the Pharmacognostical \& Pharmacological Characterization of Apium Graveolens Linn', Indo Global Journal of Pharmaceutical Sciences, vol. 2, no. 1, pp 36-42.

Kemenkes RI, 2011, Formularium Obat Herbal Asli Indonesia, vol 1, Kemenkes RI, Jakarta.

Kusnadi, K., \& Devi, E.T, 2017, 'Isolasi dan Identifikasi Senyawa Flavanoid pada Ekstrak Daun Seledri (Apium graveolens L.) dengan Metode Refluks'. Pancasakti Science Education Journal, vol. 2, no. 1, pp. 56-67.

Momin, R. \& Nair, M, 2002, 'Antioxidant, Cyclooxygenase and Topoisomerase Inhibitory Compounds from Apium graveolens Linn. Seeds', Phytomedicine, vol. 9, no. 4, pp. 312318.

Powanda, M. C. \& Rainsford, K. D, 2011, 'A Toxicological Investigation of $\mathrm{A}$ 
Celery Seed Extract Having Antiinflammatory Activity'. Inflammopharmacology, vol. 19, no. 4, pp. 227-233.

Saputra, O., \& Fitria, T, 2016, 'Khasiat Daun Seledri (Apium graveolens) Terhadap Tekanan Darah Tinggi pada Pasien Hiperkolestrolemia', Majority, vol. 5, no. 12, pp 120-125.

Setiyawan, M.P., 2005, 'Efek Diuresis Infusa Daun Seledri (Apium graveolens, Linn) pada Tikus Putih (Rattus norvegicus)'. Skripsi. Fakultas Kedokteran Hewan Universitas Airlangga, Surabaya.

Yuliantari, N.W.A., Widarta, I.W.R. \& Permana, I.D.G.M., 2017, 'Pengaruh Suhu dan Waktu Ekstraksi terhadap Kandungan Flavonoid dan Aktivitas Antioksidan Daun Sirsak (Annona muricata L.) Menggunakan Ultrasonik', Media Ilmiah Teknologi Pangan, vol. 4, no. 1, pp. 35-42.

Zainudin, A., Hasanah, U., \& Pemana, Y.R, 2015, 'Uji Aktivitas Diuretik Ekstrak Akar Aren (Arenga pinnata (Wumb.) Merr.) Terhadap Tikus Putih Galur Wistar (Rattus Norvegicus) dengan Pembanding Furosemid', Jurnal Kesehatan Prima, vol. 9, no. 1, pp. 1403-1411. 
